\title{
New Neotropical species of Ceraeochrysa Adams (Neuroptera: Chrysopidae)
}

\author{
FRANCISCO SOSA ${ }^{1} \&$ SERGIO DE FREITAS ${ }^{2}$ \\ ${ }^{\prime}$ Museo Entomológico "Dr. José Manuel Osorio" (UCOB), Universidad Centroccidental "Lisandro Alvarado", Venezuela. PhD student \\ at the Universidade Estadual Paulista, Jaboticabal, São Paulo, Brazil.E-mail: fransodu73@hotmail.com \\ ${ }^{2}$ Universidade Estadual Paulista, Jaboticabal, São Paulo, Brazil.E-mail: serfre@fcav.unesp.br
}

\begin{abstract}
Species of Ceraeochrysa Adams are distributed from southeast Canada to Argentina. Larvae feed on aphids, thrips, white flies, mites, and neonatal larvae of Lepidoptera in varied agroecosystems. Seven species are known in Venezuela, viz. Ceraeochrysa achillea Freitas \& Penny, C. angulata (Navás), C. bitacornua Freitas \& Penny, C. caligata (Banks), $C$. cubana (Hagen), C. everes (Banks), and C. valida (Banks). In this study, three species are described as new to science, Ceraeochrysa melaenopareia sp. nov., Ceraeochrysa pittieri sp. nov., and Ceraeochrysa torresi sp. nov.
\end{abstract}

Key words: Biological control, Chrysopinae, Chrysopini, green lacewing, natural control

\section{Resumen}

Las especies de Ceraeochrysa Adams están distribuidas desde el sureste de Canadá hasta Argentina. Sus larvas se alimentan de áfidos, trips, moscas blancas, ácaros y larvas de primer estadio de Lepidoptera en diversos agroecosistemas. Siete especies se conocen en Venezuela, Ceraeochrysa achillea Freitas \& Penny, C. angulata (Navás), C. bitacornua Freitas \& Penny, C. caligata (Banks), C. cubana (Hagen), C. everes (Banks) y C. valida (Banks). En este trabajo, tres especies nuevas para la ciencia son descritas, Ceraeochrysa melaenopareia $\mathbf{s p . ~ n o v . , ~ C e r a e o c h r y s a ~ p i t t i e r i ~} \mathbf{s p .}$ nov. y Ceraeochrysa torresi sp. nov.

Palabras clave: Control biológico, Chrysopinae, Chrysopini, crisopa, control natural

\section{Introduction}

Adams (1982) erected the genus Ceraeochrysa from species in the genus Chrysopa Leach, encompassing at the time 24 species distributed from southeast Canada to Argentina. In this way, the largest genus of Neotropical Chrysopinae was constituted. Brooks and Barnard (1990) carried out an important generic review of the Chrysopidae, adding another 16 species to the genus. Tauber and De León (2001) and Tauber et al. (2000) recognized 46 species. Penny (2002) and Freitas and Penny (2001) listed at least 50 valid species, and Freitas et al. (2009), in the last review of the genus, recognized 63 valid species in the Neotropics.

Countries with the highest species diversity are Mexico with 16 species (Tauber \& De León 2001), Costa Rica with 20 (Penny 1997; 1998; 2002), and Brazil with 21 (Freitas \& Penny 2001; Adams \& Penny 1987). In Venezuela, only Ceraeochrysa achillea Freitas and Penny, C. angulata (Navás), C. bitacornua Freitas and Penny, C. caligata (Banks), C. cubana (Hagen), C. everes (Banks), and C. valida (Banks) have been recorded (Banks 1944; Penny 1977; Freitas et al. 2009).

Studying this genus, as with Chrysopidae in general, is relevant because of the large number of species that inhabit agroecosystems, which contribute to the natural control of arthropod pests (Freitas \& Penny 2001). Larvae of lacewings feed on soft-bodied arthropods such as aphids, diaspidids, thrips, aleyrodids, psyllids, and neonatal larvae of Lepidoptera (Freitas 2001). Ceraeochrysa caligata (Banks), C. cincta 